\title{
THE PRESENCE OF LOWER MIOCENE (EGGENBURGIAN) IN BOREHOLE 575 CETEA (EAST OF BOROD BASIN, NW ${ }^{\text {rn }}$ ROMANIA)
}

\author{
I. PETRESCU ${ }^{1}$, M. POPA ${ }^{1}$, N. BICAN-BRIŞAN ${ }^{1}$
}

\begin{abstract}
The microfloral record evidenced in borehole 575 Cetea is very rich, consisting of 114 taxa, some of them being new species for the Tertiary of Romania. At the same time, it includes species of Eggenburgian age of the host rocks. The whole microflora assemblage suggests a forest-type vegetation developed in a warm, subtropical climate, characteristic for the Eggenburgian age of the Early Miocene. The Eggenburgian of Romania shows the same microfloral features as the Eggenburgian of Central Paratethys.
\end{abstract}

Keywords: microflora, Early Miocene (Eggenburgian), Borod Basin, $\mathrm{NW}^{\mathrm{rn}}$ Romania

\section{Introduction}

Borod Basin, located in the western part of the Apuseni Mountains, between the Plopiş Mountains (to the north) and the Pădurea Craiului Mountains (to the south) had a particular evolution during the Neogene, as compared to the basins in the neighborhood (Şimleu and Beiuş). The specific features are evidenced by the biostratigraphic aspects, which are not yet completely understood. The studies performed in the last half of the $20^{\text {th }}$ century lead to controversies concerning the age of the oldest Neogene deposits in this basin.

Givulescu (1957) has admited that this area could function as a sedimentation basin during Badenian. Still, the author considered that the Badenian deposits are missing, being eroded; thus the oldest sediments in the area are of a Sarmatian age. The fauna collected from the Lupului Brook (a tributary of Băița Valley) containing Ostrea digitalina DUB., O. cochlear POLLI (=Neopycnodonte navicularis (BROCCHI)),Crassostrea cf. crassissima LAM., Natica helicina LAM., can be considered as reworked in the basal part of the Sarmatian deposits. Paucă et al., (1968) and Istocescu \& Istocescu (1974) considered that the oldest sediments in the basin belong to the Badenian. As support for this opinion, the authors mentioned the small outcrop of white marls in the right slope of Mîşca Valley as well as the mollusks mentioned by Givulescu (considered as reworked in the base of the Sarmatian).

In 1973 Şuraru \& Şuraru described macro- and microfauna from the outcrops located between the Cetea and Băița Valleys. The assemblage is

1 "Babeş-Bolyai" University, Department of Geology, Str. Kogălniceanu 1, 3400 Cluj-Napoca, Romania. 
considered by the authors to be almost identical with those described in the Eggenburgian faciostratotypes from Central Paratethys; thus, they considered this fact as an unequivocal argument for the presence of Eggenburgian. Moreover, the authors extended the chronostratigraphic interval to Eggenburgian-Lower Ottnangian. This is due to the presence of some taxa that are common to the fauna in the basal part of the Hida Formation that were attributed by Şuraru (in Şuraru \& Gheorghian, 1971) to the Ottnangian.

The presence of Eggenburgian in the Borod Basin was documented by using macrofauna by Nicorici et al., 1977, Moisescu (in Marinescu et al., 1980 and Papaianopol et al., 1984; 1990), Popa (in Popa et al., 1997 and Popa \& Chira, 1999).

\section{Biostratigraphy of deposits from Cetea - Borozel}

Borehole 575 is located on Cetea Valley (Fig. 1) and it crossed deposits belonging to the Borod Formation in the interval 290,00-75,00 m. These sediments mainly consist of grey-blackish silty, fossiliferous marls, green to blackish clays interbedded with sand, sandstone, microconglomerate, and coal. In the interval $75,00-15,00 \mathrm{~m}$ the sediments of Cornițel Formation (Popa, 2000), consisting of greenish sandstone and microconglomerate, compact grey fossiliferous marls with intercalations of carbonate laminas in the upper part were intercepted (Fig. 2).

The macrofauna collected from the Borod Formation is rich and well preserved. Popa (in Popa \& Chira, 1999) separated three assemblages: PirenellaTheodoxus-Tympanotonos, Turritella-Anadara, and Alvania-Ringicula-Pyramidella (Fig. 2).

Only gastropod opercula were identified in the interval $290-219 \mathrm{~m}$. In the interval 190-182 m the Pirenella-Theodoxus-Tympanotonos assemblage is present and mainly contains gastropods as Pirenella plicata div. ssp. and Tympanotonos margaritaceus grateloupi d'ORBIGNY. In the Central Paratethys these taxa are known only from deposits which are not younger than the Eggenburgian. The assemblage is typical for shallow, well oxygenate brackish environments.

The Turritella-Anadara assemblage separated between 174-172 m, contains gastropods from the Pyramidellidae family. Beside it represents a normal marine salinity assemblage.

A fauna containing small sized bivalves and gastropods separated as the Alvania-Ringicula-Pyramidella assemblage characterizes a wide interval between 148 and $94 \mathrm{~m}$. The following identified taxa within this assemblage are known in Central Paratethys only from Badenian deposits: Obsoletiforma kokkupica (ANDR.), Alvania venus danubiensis COSSM. \& PEY., A. montagui ampulla (EICHW.), Turritella cf. partschi ROLLE, Cerithiopsis tubercularis astensis COSSM., Odostomia dispar BOETT., O. perrara BOETT., O. subintermedia (COSSM. \& PEY.), Eulimella nitidissima (MONT.), Chrysallida interstincta (MONT.), C. sacyi (COSSM. \& PEY.), Turbonilla scala (EICHW.), and Ringicula costata (EICHW.).

Based on the stratigraphic distribution of the studied macrofauna, Popa (in Popa \& Chira, 1999) attributed the deposits of the Borod Formation to the Eggenburgian-Badenian interval. 


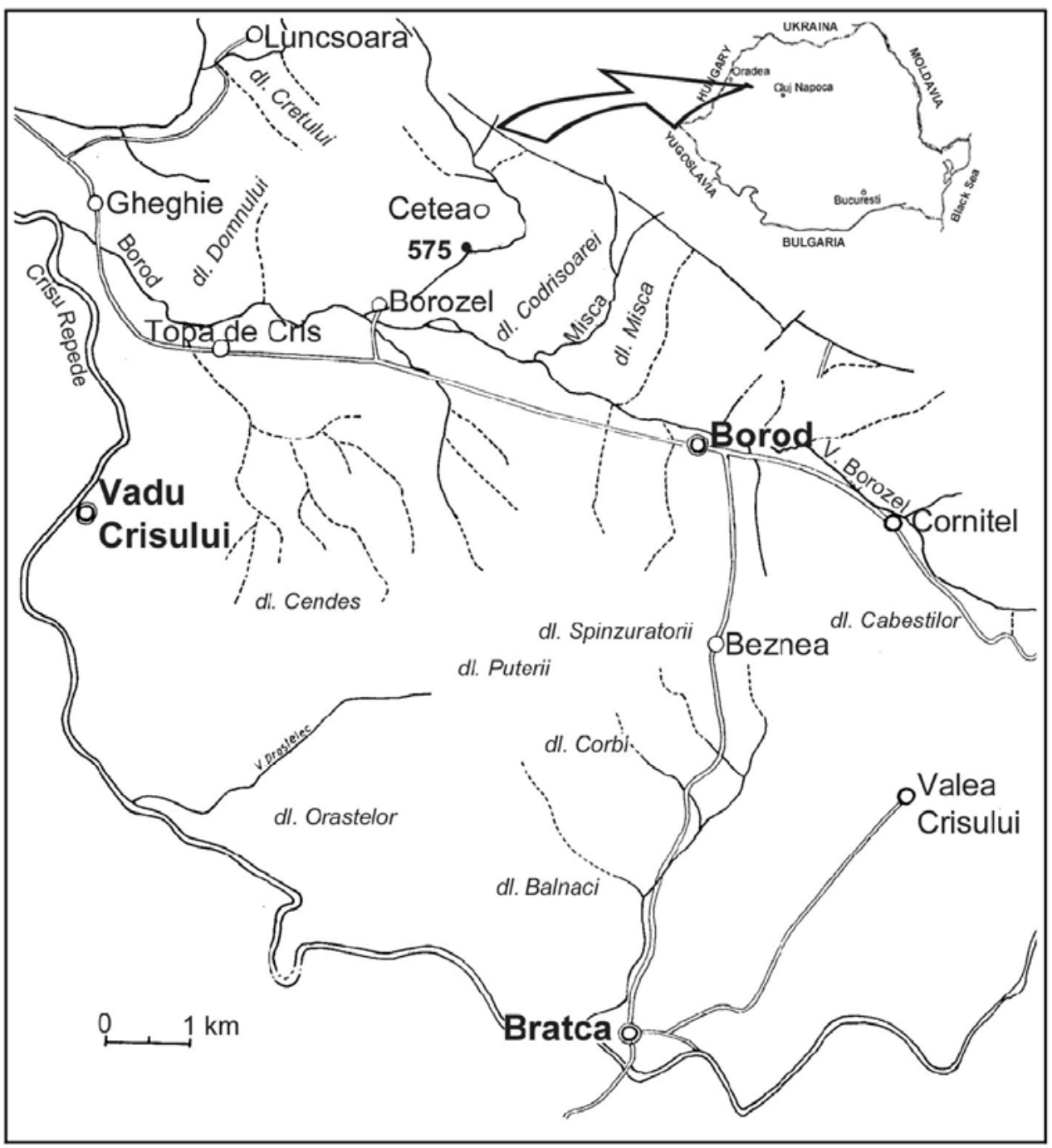

Fig. 1 Location of the 575 borehole

The nannoplankton assemblage are relatively scarce (Chira in Popa \& Chira, 1999). This interval with gastropod opercula is practically depleted. The samples collected from the interval with Pirenella-Theodoxus-Tympanotonos assemblage contained only two species, Cyclicargolithus cf. floridanus (Roth \& Hay 1967) and Sphaenolithus cf.abies Deflandre. The richest assemblage was identified in the interval with Turritella-Anadara and it contains Helicosphaera ampliaperta Bramlette \& Wilcoxon 1967, the index species for NN4 biozone (Martini, 1971). The same species is present also in the interval corresponding to the Alvania-Ringicula-Pyramidella assemblage. In the above mentioned two intervals, the species Calcidiscus leptoporus (Murray \& Blackman 1898) Loeblich \& Tappan 1978, considered by Mărunțeanu 
(1992) as the index species for subzone NN4b, and Geminilithella rotula (Kampner, 1956), species considered by Mărunțeanu (1999) as an index for subzone NN5a, were also noticed. However, the latter species is not accompanied by Sphaenolithus heteromorphus Deflandre, the index species for NN5 zone (Martini, 1971), thus the presence of Badenian cannot be documented with confidence.

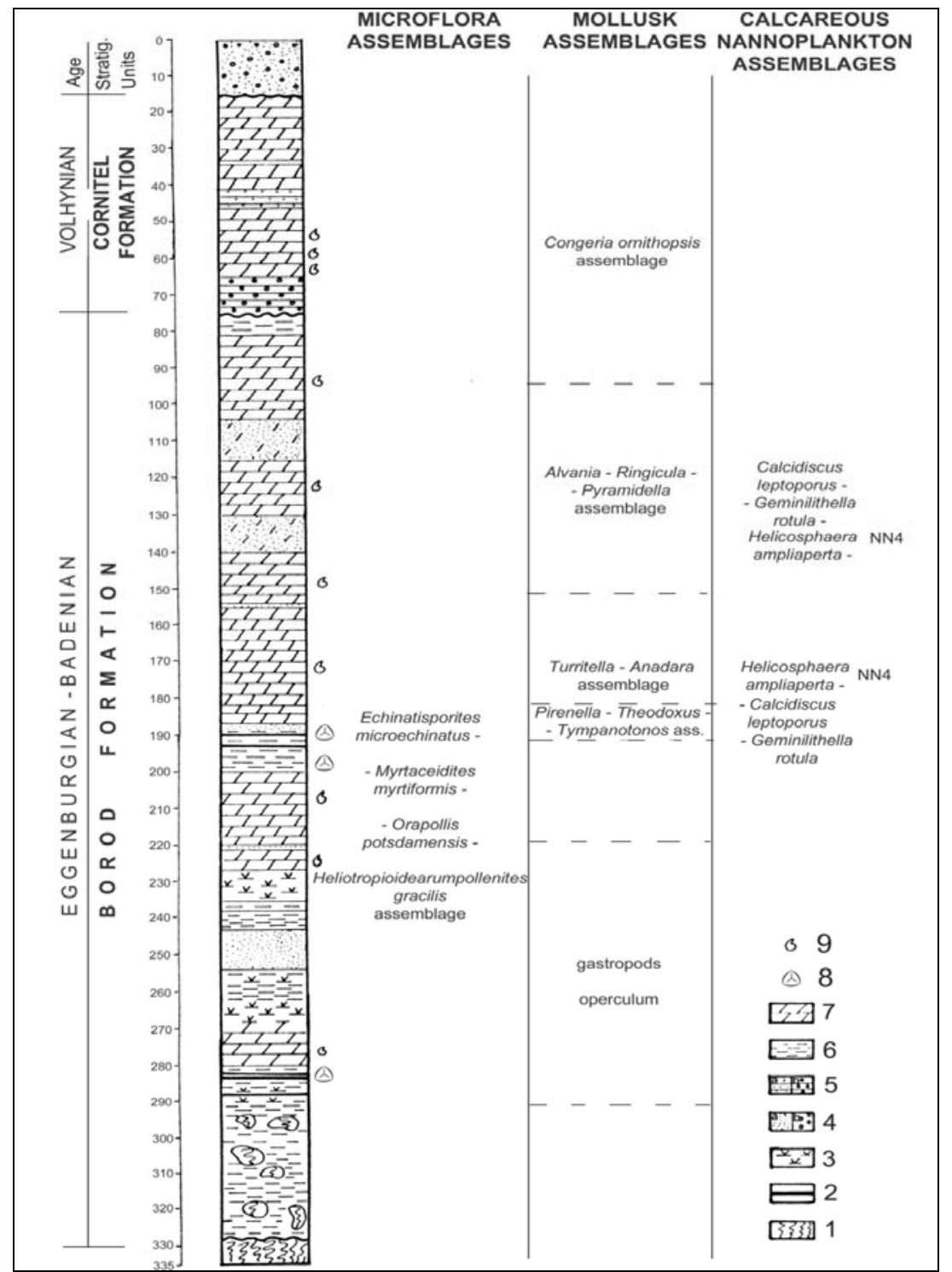

Fig. 2 Synthetic lithostratigraphic column of the Eggenburgian - Sarmatian formations of the Borod Basin; 1 - metamorphic rocks; 2 - coal; 3 - silt; $4 \mathrm{a}$ - sand, 4b - gravel; $5 \mathrm{a}$ - sandstone, $5 \mathrm{~b}$ - microconglomerate; 6 - clay; 7 - marls; 8 - pollen-spores bearing level; 9 - molluscbearing level. 
Based on the nannoplankton assemblages, the age of the Borod Formation is Ottnangian, probably Lower Badenian (Chira in Popa \& Chira, 1999).

In the neighborhood of Cetea and Borozel localities, the microfloral assemblages in five boreholes were studied (Petrescu \& Nicorici, 1977). This study evidenced rich spore-pollen assemblages in the Eggenburgian-Badenian deposits, dominated by juglandaceeans, sapotaceeans, and nyssaceeans. Among the most frequent taxa are: Triatripollenites coryphaeus microcoryphaeus, T. c. punctatus, Tetracolporopollenites div. sp., Inaperturopollenites hiatus, Tricolporopollenites kruschi, T. cingulum, T. microhenrici, T. megaexactus, Triatripollenites myricoides. A significant amount (20-35\%) of reworked Cretaceous grains was noticed, in a similar way as in the calcareous nannoplankton assemblages.

\section{Palynological study}

Recently (Petrescu et al., 1999) we described few palynological rarities from Lower Miocene (Eggenburgian) from Cetea-Borod.

25 samples (clays in general) were collected and correspondingly prepared for extracting microflora from the Lower Miocene sequence - attributed to this age based on previous macrofauna and nannoplankton data. Unfortunately, a significant part of the core samples did not preserve a convincing microflora. A satisfactory palynological record was preserved in the samples from $281.5 \mathrm{~m} ; 194.5 \mathrm{~m}$ and $187.5 \mathrm{~m}$. Only sample at $\mathrm{m}$. 185.9 preserved a rich microflora - and most of the following data are based on the study of this sample.

Table 1 presents the record of the identified microflora.

Tab.1

\begin{tabular}{lc}
\hline \multicolumn{1}{c}{ TAXA } & FREQUENCY \\
\hline CHLOROPHYTA & $\bullet$ \\
1. Botryococcus sp. & \\
PTERIDOPHYTA. & $\circ$ \\
1. Leiotriletes maxoides maxoides W. Kr. 1962 & $\circ$ \\
2. Leiotriletes maxoides minoris W. Kr. 1962 & $\circ$ \\
3. Leiotriletes asp. microsinuosoides W. Kr. 1962 & $\circ$ \\
4. Leiotriletes triangulus (Murr.-Pf. 1952 ex.Kr. 1953) W. Kr. 1962 & $\circ$ \\
5. Neogenisporis sp. & $\circ$ \\
6. Undulatisporites sp. & $\bullet$ \\
7. Corrugatisporites corruvallatus (W. Kr. 1967) Nagy 1985 & $\bullet$ \\
8. Corrugatisporites multivallatus (W. Kr. 1959) Planderova 1990 & $\bullet$ \\
9. Corrugatisporites sp. & $\bullet$ \\
10. Foveotriletes verrucatoides W. Kr. 1962 & $\circ$ \\
11. Foveotriletes sp. & $\circ$ \\
12. Favoisporis trifavus W. Kr. 1959 & $\circ$ \\
13. Baculatisporites gr. primarius (Wolff 1934) Th. et Pf. 1953 & $\circ$ \\
14. Lusatisporis punctatus W. Kr. 1963 & $\circ$ \\
15. Echinatisporites cycloides W. Kr. 1963 & $\circ$ \\
16. Echinatisporites microechinatus W. Kr. 1963 & $\circ$ \\
17. Echinatisporites miocaenicus W. Kr. 1963 & $\circ$ \\
18. Laevigatisporites gracilis Wilson et Webster 1946 & $\bullet$ \\
19. Laevigatisporites haardti (Pot. et Ven. 1934) Th. et Pf. 1953 & $\circ$ \\
20. Laevigatisporites pseudodiscordatus W. Kr. 1959 & $\circ$ \\
21. Extrapunctatosporis alveolatus (Couper 1960) W. Kr. 1967 & $\circ$ \\
22. Extrapunctatosporis megapunctos W. Kr. 1959 & $\circ$ \\
23. Perinomoletes spicatus Nagy 1973 & $\bullet$ \\
\hline
\end{tabular}


I. PETRESCU, M. POPA, N. BICAN-BRIŞAN

\begin{tabular}{|c|c|}
\hline TAXA & FREQUENCY \\
\hline 24. Echinatisporites sp. & $\bullet$ \\
\hline 25. Verrucatosporites alienus (Pot. 1931) Th. et Pf. 1953 & ○ \\
\hline 26. Verrucatosporites clatriformis (Murr.- Pf. 1952) W. Kr. 1967 & 0 \\
\hline 27. Verrucatosporites favus (Pot. 1931) Th. et Pf. 1953 & $\bullet \bullet$ \\
\hline 28. Verrucatosporites megabalticus W. Kr. 1967 megabalticus n. sfsp. & o \\
\hline 29. Verrucatosporites cf. potoniei (Nagy 1969) n.c. & 0 \\
\hline 30. Polypodiaceoisporites corrutoratus Nagy 1985 & - \\
\hline 31. Polypodiaceoisporites cyclocingulatus W. Kr. 1967 & - \\
\hline 32. Polypodiaceoisporites gracillimus Nagy 1963 & $\bullet$ \\
\hline 33. Polypodiaceoisporites hidasensis Nagy 1969 & o \\
\hline 34. Polypodiaceoisporites Iusaticus W. Kr. 1967 & $\bullet$ \\
\hline 35. Polypodiaceoisporites mecsekensis Nagy 1969 & ० \\
\hline 36. Polypodiaceoisporites pauciornatus Nagy 1985 & 0 \\
\hline 37. Polypodiaceoisporites saxonicus W. Kr. 1967 & 0 \\
\hline 38. Polypodiaceoisporites verrucosus Nagy 1969 megaverrucosus n. sfsp. & 0 \\
\hline $\begin{array}{l}\text { 39. Undulozonosporites sp. } \\
\text { GYMNOSPERMATOPHYTA. CHLAMIDOSPERMATOPSIDA }\end{array}$ & ○ \\
\hline $\begin{array}{l}\text { 1. Ephedripites (D.) cf. claricristatus (Shakmundes 1965) W. Kr. } 1970 \\
\text { GYMNOSPERMATOPHYTA. CONIFEROPSIDA }\end{array}$ & ○ \\
\hline 1. Sequoiapollenites gracilis W. Kr. 1971 & ○ \\
\hline 2. Sequoiapollenites megaligulus W. Kr. 1971 & ○ \\
\hline 3. Sequoiapollenites polyformosus Thg. 1937 & 0 \\
\hline 4. Inaperturopollenites concedipites (Wodeh. 1933) W. Kr. 1971 & ○ \\
\hline 5. Inaperturopollenites verrupapillatus Trevisan 1967 & ० \\
\hline 6. Cupressacites bockwitzensis W. Kr. 1971 & - \\
\hline 7. Podocarpidites libellus (Pot. 1931) W. Kr.1971 & o \\
\hline 8. Abiespollenites cedroides (Thomson 1953) W. Kr. 1971 & 0 \\
\hline 9. Abiespollenites sp. & 0 \\
\hline 10. Cedripites crassiundulicristatus (Trevisan 1967) W. Kr. 1971 & - \\
\hline 11. Cedripites cf. miocaenicus W. Kr. 1971 & - \\
\hline 12. Pityosporites microalatus (Pot. 1931) Th. et Pf. 1953 & $\bullet \bullet$ \\
\hline 13. Pityosporites labdacus (Pot. 1931) Th. et Pf. 1953 & 0 \\
\hline 14. Pityosporites latisaccatus medius Trevisan 1967 & 0 \\
\hline 15. Pityosporites longus (Nagy 1985) n.c. & ○ \\
\hline 16. Pityosporites pristinipollinius (Trav. 1955) W. Kr. 1971 & o \\
\hline 17. Pityosporites scopulipites (Wdh. 1933) W. Kr. 1971 & 0 \\
\hline 18. Piceapollenites neogenicus (Nagy 1969) & 0 \\
\hline ANGIOSPERMATOPHYTA. MONOCOTYLEDONATAE & \\
\hline 1. Sparganiaceaepollenites polygonalis Thg. 1937 & - \\
\hline 2. Sparganiaceaepollenites sparganioides (Meyer 1956) W. Kr. 1970 & 0 \\
\hline 3. Monocolpopollenites tranquillus (Pot 1934) Th. et Pf. 1953 & - \\
\hline 4. Monocolpopollenites arcuatus $\mathrm{n}$. sp. & 0 \\
\hline 5. Arecipites parareolatus (W. Kr. 1958) W. Kr. 1970 & 0 \\
\hline 6. Arecipites gr. pseudoconvexus W. Kr. 1970 & 0 \\
\hline 7. Arecipites sp. & 0 \\
\hline 8. Dicolpopollis kockeli Pflanzl 1956 & 0 \\
\hline ANGIOSPERMATOPHYTA. DICOTYLEDONATAE & \\
\hline 1. Magnolipollis neogenicus major W. Kr. 1970 & ○ \\
\hline 2. Gothanipollis gothani crucis W. Kr. 1959 & o \\
\hline 3. Myrtaceidites myrtiformis Simoncsics 1964 & • \\
\hline 4. Triatriopollenites myricoides (Kremp 1950) Th. et Pf. 1953 & - \\
\hline 5. Triatriopollenites bituitus (Pot. 1931) Th. et Pf. 1953 & 0 \\
\hline
\end{tabular}


THE PRESENCE OF LOWER MIOCENE (EGGENBURGIAN) IN BOREHOLE 575 CETEA

\begin{tabular}{|c|c|}
\hline TAXA & FREQUENCY \\
\hline 6. Triatriopollenites rurensis Th. et Pf. 1953 & o \\
\hline $\begin{array}{c}\text { 7. Engelhardtioidites microcoryphaeus (Pot. 1931) Thomson et Thg. ex } \\
\text { Pot. 1960 }\end{array}$ & $\bullet \bullet$ \\
\hline 8. Momipites punctatus (Pot. 1931) Nagy 1969 & - \\
\hline 9. Platycaryapollenites miocaenicus Nagy 1969 & 0 \\
\hline 10. Plicatopollis plicatus (Pot. 1934) W. Kr. 1962 & 0 \\
\hline 11. Caryapollenites simplex (Pot. 1931) W. Kr. 1960 & $\bullet \bullet$ \\
\hline 12. Pterocaryapollnites stellatus (Pot. 1931) Thg. 1937 & 0 \\
\hline 13. Ulmipollenites undulosus Wolff 1934 & 0 \\
\hline 14. Zelkovaepollenites thiergarti Nagy 1969 & 0 \\
\hline 15. Trivestibulopollenites betuloides Pflug 1953 & 0 \\
\hline 16. Alnipollenites verus (Pot. 1931) Pot. 1934 & $\bullet$ \\
\hline 17. Salixpollenites densibaculatus Nagy 1969 & O \\
\hline 18. Intratriporopollenites instructus (Pot. 1931) Th. et Pf. 1953 & o \\
\hline 19. Intratriporopollenites insculptus Mai 1961 & o \\
\hline 20. Reevesiapollis triangulus (Mamczar 1960) W. Kr. 1970 & 0 \\
\hline 21. Olaxipollis mathesi W. Kr. 1962 & 0 \\
\hline 22. Porocolpopollenites vestibulum (Pot. 1931) Th. et Pf. 1953 & 0 \\
\hline 23. Buxapollis buxoides W. Kr. 1966 & 0 \\
\hline 24. Punctioratipollis ludwigi W. Kr. 1966 & 0 \\
\hline 25. Heliotropioidearumpollenites gracilis Nagy 1969 & 0 \\
\hline 26. Chenopodipollis multiplex (Weyl. et Pf. 1957) W. Kr. 1966 & 0 \\
\hline 27. Tricolpopollenites liblarensis (Th. 1950) Th. et Pf. 1953 & o \\
\hline 28. Tricolporopollenites cingulum (Pot. 1931) Th. et Pf. 1953 & ○ \\
\hline 29. Tricolporopollenites pseudocingulum (Pot. 1931) Th. et Pf. 1953 & 0 \\
\hline 30. Tricolporopollenites villensis (Th. 1950) Th. et Pf. 1953 & 0 \\
\hline 31. Tricolporopollenites henrici (Pot. 1931) W. Kr. 1960 & • \\
\hline 32. Tricolporopollenites microhenrici (Pot. 1930) W. Kr. 1960 & - \\
\hline 33. Tricolporopollenites spinus W. Kr. 1962 & o \\
\hline 34. Tricolporopollenites marcodurensis Pf. et Th. 1953 & - \\
\hline 35. Araliaceoipollenites edmundi (Pot. 1931) Pot. 1951 & • \\
\hline 36. Faguspollenites verus Raatz 1937 & 0 \\
\hline 37. Cystacearumpollenites rotundus Nagy 1969 & 0 \\
\hline 38. Nyssapollenites kruschi (Pot. 1931) Nagy 1969 & - \\
\hline 39. Cyrillaceaepollenites exactus (Pot. 1931) Pot. 1960 & $\bullet$ \\
\hline 40. Cyrillaceaepollenites megaexactus (Pot. 1931) R. Pot. 1960 & ○ \\
\hline 41. Ilexpollenites margaritatus (Pot. 1931) Thg. 1937 & 0 \\
\hline 42. Ilexpollenites iliacus (Pot. 1931) Thg. 1937 & o \\
\hline 43. Caprifoliipites gracilis Nagy 1969 & • \\
\hline 44. Tetracolporopollenites sapotoides Pf. et Th. 1953 & - \\
\hline 45. Tetracolporopollenites microrhombus Pf. 1953 & 0 \\
\hline $\begin{array}{l}\text { 46. Tetracolporopollenites manifestus (Pot. 1931) Th. et Pf. } 1953 \text { contractus } \\
\text { Pf. } 1953\end{array}$ & • \\
\hline 47. Ericipites callidus (Pot. 1931) W. Kr. 1970 & 0 \\
\hline
\end{tabular}

Frequency:

$$
\begin{aligned}
& \bullet-\text { frequent (10 - } 20 \text { grains). } \\
& \text { - - rare (3 - } 9 \text { grains); } \\
& \circ \text { - very rare (1 - } 2 \text { grains); }
\end{aligned}
$$


Green algae are represented by colonies of Botryoccocus, which are abundant in the interval. $281.5 \mathrm{~m}-280 \mathrm{~m}$. It is possible that the decrease of the salinity in the proximal area of the sedimentation basin lead to the significant development of these algae.

The spores of Pteridophyta show a great variety (39 morphological types) but a small number of forms are frequent: Corrugatisporites, Laevigatisporites and Verrucatosporites.

Quantitatively, the pteridophyte spores represent $12-18 \%$.

The pollen of Coniferopsida is attributed to 18 types, among which the most frequent are the grains of Pityosporites microalatus, Cedripites and Taxodiaceae.

Quantitatively, this type of pollen represents $8-15 \%$. The pollen of Pityosporites is more frequent in the upper part of the profile (attributed to the Lower Miocene).

Monocotyledonous angiosperms show low frequencies $(1-3 \%)$. Relatively diversified are the palms (Monocolpopollenites, Arecipites, Dicolpopollis), besides which the monopore pollen of Sparganiaceaepollenites was also identified.

Dicotyledonous angiosperms are dominant in all the analyzed samples (70 - $75 \%$ ). The list contains 47 types.

The most frequent pollen belongs to Engelhardtioidites, Caryapollenites, Araliaceoipollenites, Cyrillaceaepollenites, Triatriopollenites, Tetracolporopollenites. Relatively rare are the forms of Myrtaceidites, Momipites, Ulmipollenites, Porocolpopollenites, Tricolporopollenites cingulum, T. microhenrici, T. marcodurensis, Nyssapollenites, etc.

Some dicotyledonous types were identified for the first time in the palynological record of Romania (Punctioratipollis ludwigi, Heliotropioidearumpollenites gracilis, Salixpollenites densibaculatus). Other forms are mentioned for the first time in Lower Miocene deposits in our country: Gothanipollis gothani, Olaxipollis mathesi, Buxapollis buxoides, Tricolporopollenites spinus etc.

The paleoclimatic significance of the identified microflora can be drawn according to the following indices:

- the great diversity of the spores of Pteridophytes, as well as their significant amount (in some samples up to 18\%) plead for a humid. The frequency of the spores of Corrugatisporites, Verrucatosporites favus or the frequency of the spores of Leiotriletes maxoides etc. prove a warm, subtropical continental environment;

- the same type of climate is indicated by the presence of palm pollen;

- a significant amount of the identified dicotyledonous angiosperms consists of forms characterizing a macrotherm climate: Myrtaceidites, Engelhardtioidites, Platycaryapollenites, Reevesiapollis, Buxapollis, Araliaceoipollenites, Cyrillaceaepollenites, Tetracolporopollenites;

- the temperate climate is represented by a small number of forms, proving a vertical zonation of the trees that generated the pollen. It is the case of some coniferals belonging to Pinus sg. diploxylon, Abies or of some dicotyledonous angiospermes such as Ulmipollenites, Faguspollenites, etc.

Generally, the studied microflora was generated by a forest vegetation that was developed during a warm interval of the Early Miocene (Eggenburgian). 
The biostratigraphic importance of the studied microflora can be judged only by taking into account the vertical zonation of the identified taxa, as well as their frequency. Echinatisporites microechinatus, Myrtaceidites myrtiformis, Punctioratipollis ludwigi, Heliotropioidearupollenites gracilis etc. are the main forms of pollenspores proving the Eggenburgian age of the deposits where they originated.

\section{The
assemblages}

The correlation between the studied microflora and other similar

The Eggenburgian age is palynologically documented in boreholes from the Borod Basin (Petrescu \& Nicorici, 1977), and the Pebea Basin respectively (Petrescu \& Fazecas, 1989). At Coasta Mare (Cluj-Napoca) the Chechiş Clays (Upper Eggenburgian) preserved an interesting palynological record (Nicorici et al. 1979). In boreholes F 68 Sobolciu and F 48 Pețchea (Petrescu, Nicorici, 1987) the Lower Miocene deposits host a well preserved microflora, having at least an Eggenburgian age.

Planderova (1990) analyzed an Eggenburgian microflora from Slovakia formed in a warm, subtropical climate. The microfloral record contained: Leiotriletes maxoides, Tricolporopollenites cingulum, Tricolporopollenites henrici, T. microhenrici, Triatriopollenites myricoides, T. bituitus, Cyrillaceaepollenites etc.

Based on microflora, Nagy (1992) separated the Eggenburgian PN3 zone, i.e. the zone with "Verrucingulatisporites grandis and Foveotriletes pessinensis". Among the numerous forms specific for this zone, Echinatisporites microechinatus, Laevigatisporites pseudodiscordatus, Heliotropioidearupollenites gracilis etc. were mentioned. The list of the Eggenburgian forms identified in Hungary is very long; some of the forms were not identified in the Eggenburgian deposits which we investigated. Finally, there are some forms which are specific only for the Eggenburgian deposits in Romania.

Generally, the Eggenburgian deposits in Romania are similar to deposits of the same age in the Central Paratethys, concerning the microflora (Planderova, 1971).

Acknowledgements

Thanks to Dr. Sorin Filipescu for the review of the manuscript and to Dr. Dana Pop for the English translation.

\section{REFERENCES}

1. Givulescu, R., (1957), Cercetări geologice în bazinul neogen al Borodului (Reg.Oradea). Acad. RPR Cluj, Stud. Cerc. St., Geol. - Geogr., VIII/ 1-2, p. 99-158, 20 fig., Cluj.

2. Istocescu, D., Istocescu, F., (1974), Considerații geologice asupra depozitelor neogene ale bazinului Crişurilor. Stud. Cerc. Geol.geogr. geof. (Geol.), Acad. RSR, 19, p. $115-$ 127, Bucureşti.

3. Marinescu, Fl., Bițoianu C., Olteanu, R., Papaianopol, I., Popescu, A., Rădan, S., Rogge-Păranu, E., Bicleanu, N., (1980), Raport - Studiul geologic complex al formațiunilor neogene din partea de vest a bazinului Borod în vedera stabilirii condițiilor de acumulare a cărbunilor. Arhiva Transgex, Cluj - Napoca.

4. Martini, E., (1971), Standard tertiary and Quaternary calcareous nannoplankton. In Farinacci A. (Ed.), 1971: Proc. II Plankt. Conf. Roma, 1970, 2, p. 739 - 785, Roma. 
5. Mărunțeanu, M., (1992), Distribution of the Miocene calcareous nannofossils in the Intra- and Extra-Carpathian areas of Romania. Knihovnicka ZPN, 14b, 2, p. $247-261$, Hodonin.

6. Mărunțeanu, M., (1999), Litho- and biostratigraphy (calcareous nannoplankton) of the Miocene deposits from the Outer Moldavides. Geologica Carpathica, 50, 4, p. 313 324, 3 fig., 4 pl., Bratislava.

7. Moisescu, V., (1990), Mollusques miocenes du Basin de Borod. Dări de Seamă, Inst. Geol. Geofiz., vol. 74/3 ( 1987 ), 1990, p. 169 - 194, 2 fig., 11 pl., Bucureşti.

8. Nagy, E., (1992), A comprehensive study of Neogene Sporomorphs in Hungary. Geologica Hungarica, 53, 379p., 79 fig., 19 tab., 4 pl., Budapest.

9. Nicorici, E., Mureşan, I., Duşa, A., Petrescu, J., Bedelean, I., Ghergari, L., Băluță, C., Gabos, L., (1977), Studiul biostratigrafic şi petrografic al formațiunilor neogene din perimetrul Borozel - bazinul Borodului. Arhiva Transgex, Cluj - Napoca.

10. Nicorici, E., Petrescu, I., Mészáros, N., (1979), Contribuții la cunoaşterea Miocenului inferior şi mediu de la Coasta cea Mare (Cluj-Napoca). St. si cerc. geol., geof., Geogr., s. geologie 24, p. 103-137, 10 pl., Bucureşti.

11. Papaianopol, I., Artin, L., Bițoianu, C., Costea, C., Dumitrică, P., Jipa, D., Macalet, R., Marinescu, FL., Moisescu, V., Olteanu, R., Ponta, GH., Popescu, A., Rădan, S., Rogge, E., Roman, ŞT., Picleanu, N., (1984), Studiul complex al Bazinului Borod din punct de vedere al genezei şi acumulării cărbunilor; redactarea hărții humitogenetice. Arhiva Transgex, Cluj-Napoca.

12. Paucă, M., Istocescu, D., Istocescu, F., (1968), Bazinul neogen al Vadului. D.S., LIV/1, Bucureşti.

13. Petrescu, I., Nicorici, E., (1977), Contribuții biostratigrafice la cunoaşterea formațiunilor neogene din Bazinul Borod (sectorul Borozel). Nymphaea, V, p. 37-52, 1 fig., 9 pl., Oradea.

14. Petrescu, I., Nicorici, E., (1987), La presence du Miocène inferieur á charbons dans les forages du ouest du Bassin Vad-Borod (NV de la Roumanie). Studia Univ. BabeşBolyai, Geol.-Geogr., XXXII, 1, p. 13-19, Cluj.

15. Petrescu, I., Fazecaş, M., (1989), A few data on the Miocene microflora in borehole 18 - Țebea (the Brad - Săcărâmb Basin). Studia Univ. Babes-Bolyai, XXXIV/2, p. 53-60, 1 fig., 3 pl., 1 tab., Cluj-Napoca.

16. Petrescu, I., Bican-Brişan, N., Popa, M., (1999), Palynological rarities in the Lower Miocene (Eggenburgian) from Cetea-Borod (NW ${ }^{n}$ Romania). Contribuții Botanice I, (1999-2000), p. 165-175, 1 tab., 1 pl., Cluj-Napoca.

17. Planderova, E., (1971), Palynologische Charakteristik der Eggenburger Schichtengruppe. Chronostratigraphie und Neostratotypen, M-1, p. 118-809, Bratislava

18. Planderova, E., (1990), Miocene Microflora of Slovak Central Paratethys and its Biostratigraphical Significance. Dionýz Štúr Institute of Geology, Bratislava.

19. Popa, M., Chira, C., Mészáros, N., (1997), Miocene mollusks and nannoplankton of the eastern part of the Borod depression. Univ. Bucureşti. Acta Paleontologica Romaniae (1997), 1, p. 129 - 133, 3 fig, 3 pl, Bucureşti.

20. Popa, M., Chira, C. (1999), Miocene Mollusk and calcareous Nannoplankton assemblages from the Borod Formation (Borod Basin, Romania). In press.

21. Popa, M., (2000), Lithostratigraphy of the Miocene deposits in the eastern part of Borod Basin (NW of Romania). In press.

22. Şuraru, N., Gheorghian, M., (1971), Sur quelques affleurements de dépots ottnangiens de Roumanie et sur leur contenu microfaunique. Mem. Comité Geol. Inst. Geol., 14, p. 103-119, Bucureşti.

23. Şuraru, N., Şuraru, M., (1973), Asupra prezentei miocenului inferior în bazinul Borod (Bihor). Studia, Univ. Babeş-Bolyai, Geol-Min., XVIII/2, p. 29 - 38, 1 tab., 1 fig., Cluj Napoca. 


\section{Plate I (1000x)}

Fig. 1. Leiotriletes maxoides minoris Krutzsch, 1962

Fig. 2. Lusatisporis punctatus Krutzsch, 1963

Fig. 3. Verrucatosporites clatriformis (Murriger-Pflug, 1952) Krutzsch, 1967

Fig. 4. Leiotriletes asp. microsinuosoides Krutzsch, 1962

Fig. 5. Laevigatisporites pseudodiscordatus Krutzsch, 1959 (800x)

Fig. 6. Corrugatisporites corruvallatus (Krutzsch, 1967) Nagy, 1985

\section{Plate II (1000x)}

Fig. 1. Corrugatisporites multivallatus (Krutzsch, 1959) Planderova, 1990

Fig. 2. Perinomoletes spicatus Nagy, 1973

Fig. 3. Verrucatosporites alienus (Potonie, 1931) Thomson et Pflug, 1953

Fig. 4. Extrapunctatisporites miocaenicus Krutzsch, 1967

Fig. 5. Polypodiaceoisporites cyclocingulatus Krutzsch, 1967

Fig. 6. Polypodiaceoisporites gracillimus Nagy, 1963

Plate III (1000x)

Fig. 1. Verrucingulatisporites cf. miocaenicus Nagy, 1969

Fig. 2. Podocarpidites libellus (Potonie, 1931) Krutzsch, 1971

Fig. 3. Sequoiapollenites megaligulus Krutzsch, 1971

Fig. 4. Cedripites crassiundulicristatus (Trevisan, 1967) Krutzsch, 1971

Fig. 5. Inaperturopollenites concedipites (Wodeh., 1933) Krutzsch, 1971

Fig. 6. Sequoiapollenites polyformosus Thiergart, 1937

Fig. 7. Sequoiapollenites gracilis Krutzsch, 1971

\section{Plate IV (1000x)}

Fig. 1. Pityosporites microalatus (Potonie, 1931) Thomson et Pflug, 1953

Fig. 2. Pityosporites latisaccatus medius Trevisan, 1967

Fig. 3. Magnolipollis neogenicus major Krutzsch, 1970

Fig. 4., 5. Monocolpopollenites arcuatus n.sp.

Fig. 6., 7. Dicolpopollis kockeli Pflanzl 1956

Fig. 8., 9. Myrtaceidites myrtiformis Simoncsics, 1964

Fig. 10. Gothanipollis gothani Krutzsch, 1959

Fig. 11. Arecipites gr. pseudoconvexus Krutzsch, 1970

\section{Plate V (1000x)}

Fig. 1. Pityosporites pristinipollinius (Traverse, 1955) Krutzsch, 1971

Fig. 2. Arecipites gr. parareolatus (Krutzsch, 1958) Krutzsch, 1970

Fig. 3. Momipites punctatus (Potonie, 1931) Nagy, 1969

Fig. 4. Engelhardtioidites microcoryphaeus (Potonie, 1931) Thomson et Thiergart ex. Potonie, 1960.

Fig. 5. Heliotropioidearumpollenites gracilis Nagy, 1969

Fig. 6. Cyrillaceaepollenites exactus (Potonie, 1931) Potonie, 1960

Fig. 7. Salixpollenites densibaculatus Nagy, 1969

Fig. 8. Tetracolporopollenites sapotoides Pflug et Thomson, 1953

Fig. 9. Punctioratipollis ludwigi Krutzsch, 1966

Fig. 10. Triatriopollenites myricoides (Kremp 1950) Th. et Pf. 1953

Fig. 11. Pterocaryapollenites stellatus (Potonie, 1931) Thiergart, 1937

Fig. 12. Faguspollenites verus Raatz, 1937

Fig. 13. Cystacearumpollenites rotundus Nagy, 1969 


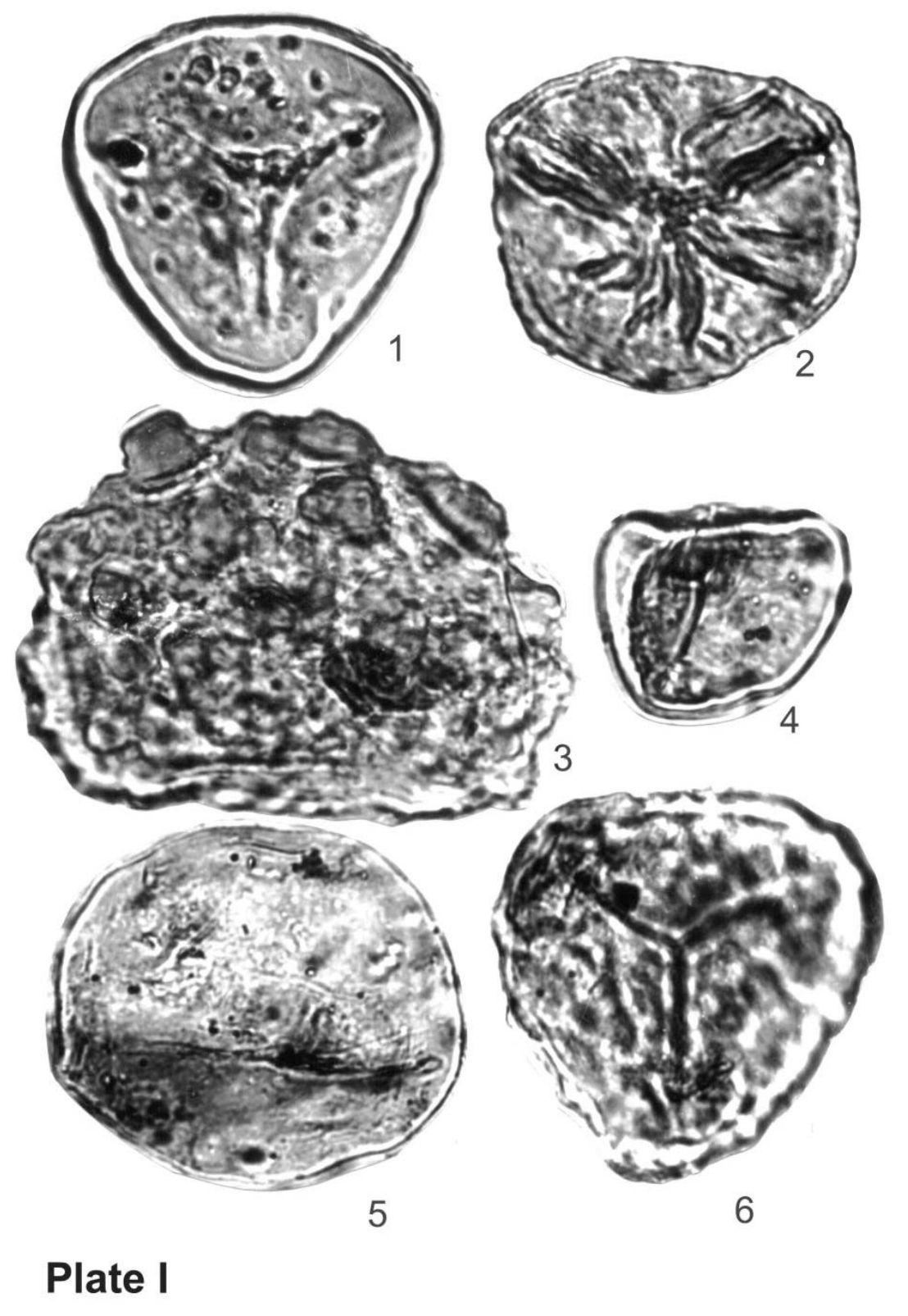



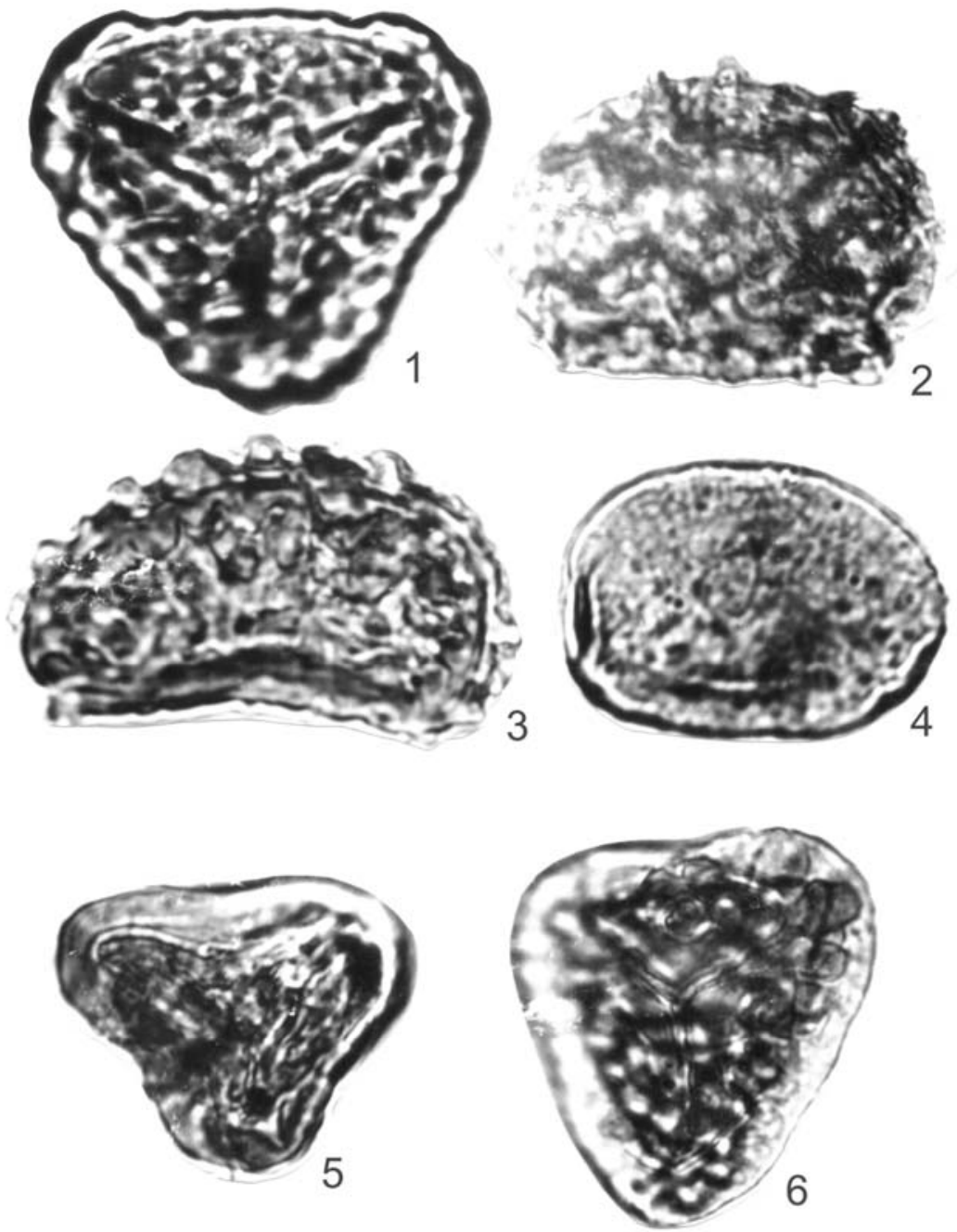

Plate II 

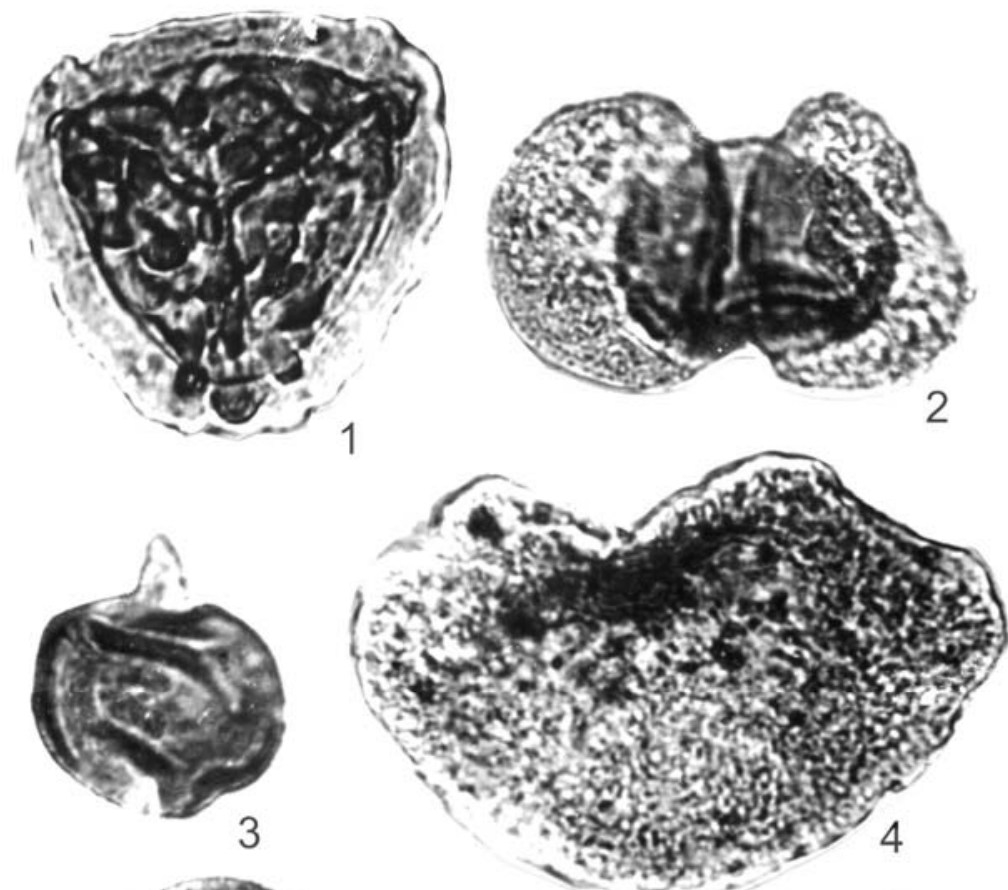

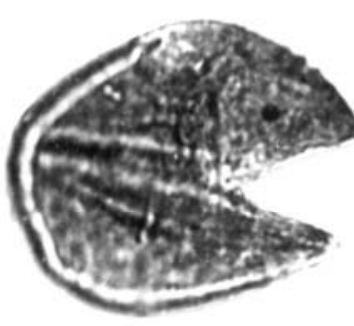

5

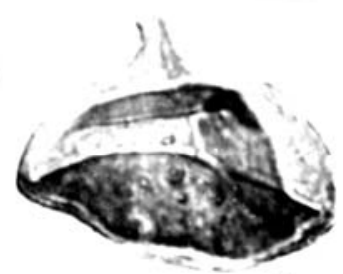

6

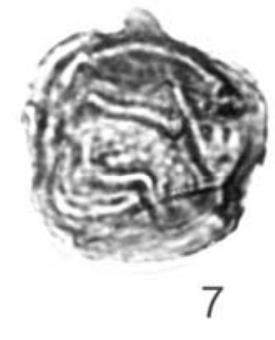

Plate III 
THE PRESENCE OF LOWER MIOCENE (EGGENBURGIAN) IN BOREHOLE 575 CETEA

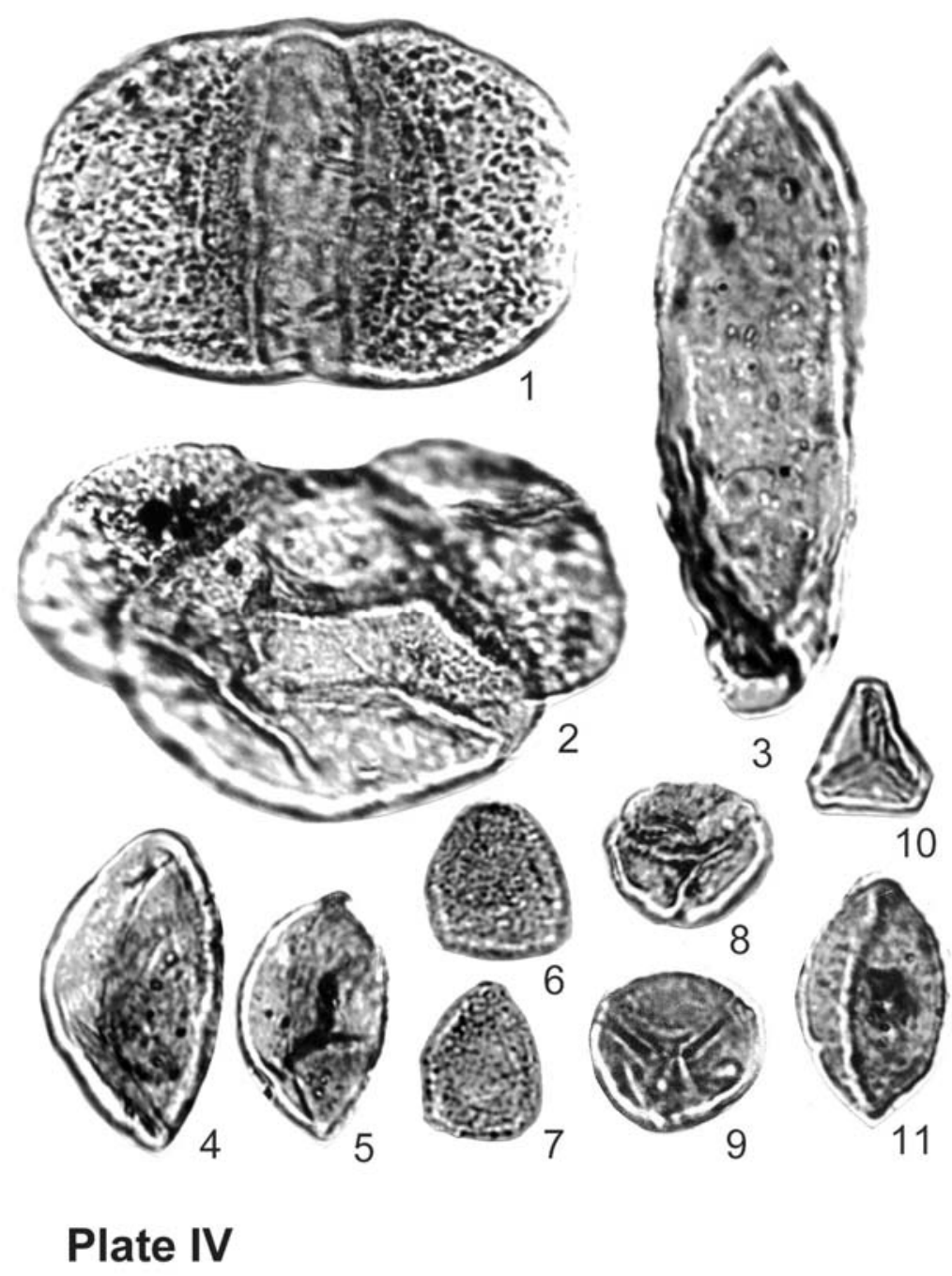




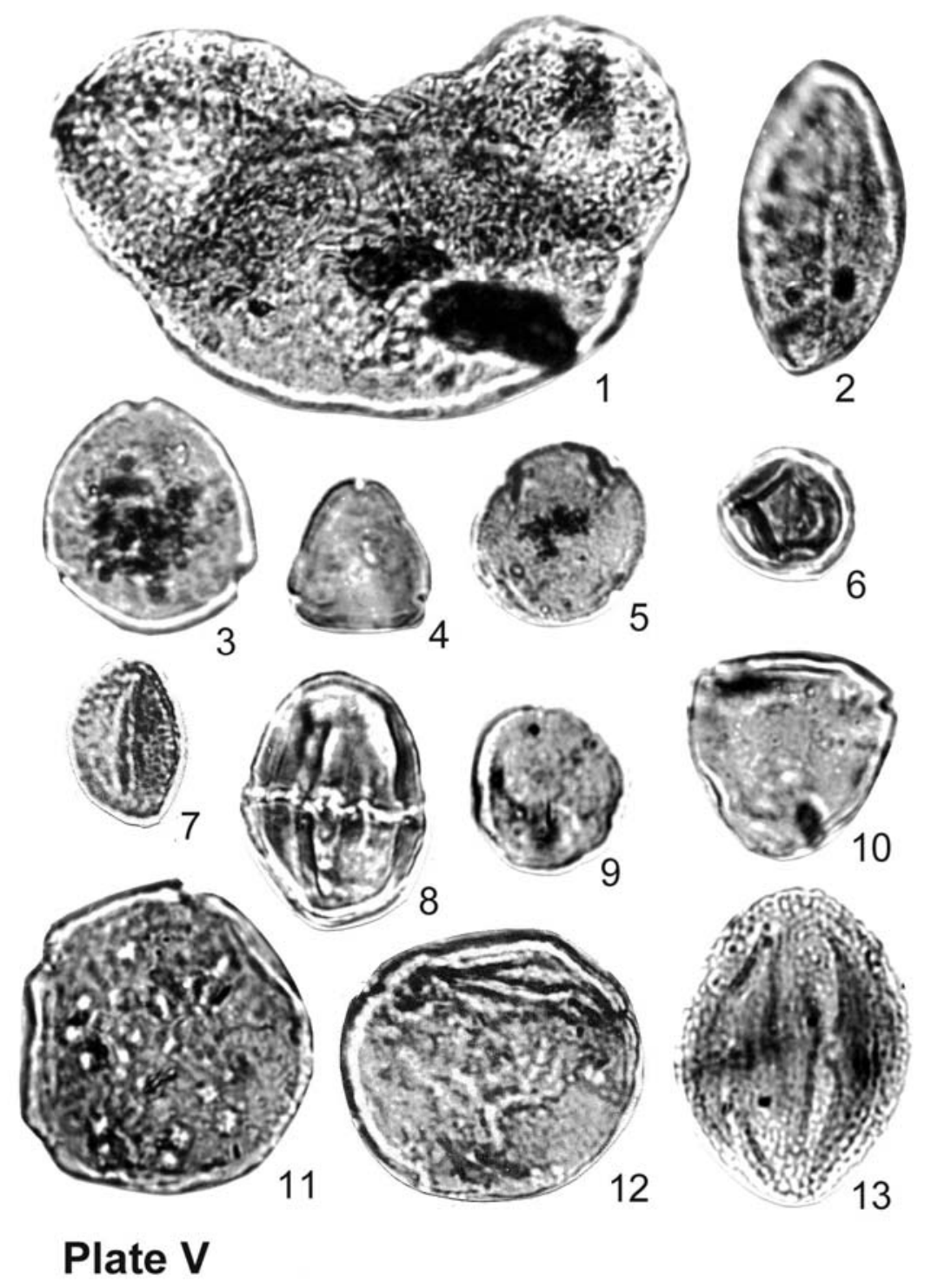

